\title{
Effect of Sparasis crispa Extract on 5a-Reductase Gene in Dermal Papilla Cells
}

\author{
Hyo-Sang $\operatorname{Han}^{1}$ \\ ${ }^{1}$ Professor, Department of Health Administration, Joongbu University, Korea, hanhs@joongbu.ac.kr
}

\begin{abstract}
Sparasis crispa (Cauliflower Mushroom) is widely used as a cosmetic product to promote hair growth, and most research on mouse hair growth has been reported. However, the study of the effects of Sparasis crispa on dermal papilla (DP) cells, which play an important role in hair growth, is not well known. For this reason, the researchers studied the effect of Sparasis crispa on DP cells. The strong antioxidant activity of Sparasis crispa was confirmed by ABTS analysis. In MTS analysis, 2 $\mathrm{mg} / \mathrm{mL}$ of Sparasis crispa was treated, reducing cell survival to $160.2 \%$ in DP cells and no cytotoxicity was observed at $1 \mathrm{mg} / \mathrm{mL}$ concentration. The level of mRNA expression of the BMP6, FGF7, FGF10, CTNNB1, SRD5A1, SRD5A2 involved in hair cycle and hair loss induction was measured as quantitative RT-PCR after the Sparasis crispa treatment. Significant change in mRNA expression of type I 5 alpha-reductase could be identified if Sparasis crispa with a concentration of $0.5 \mathrm{mg} / \mathrm{ml}$ was treated in DP cells. Additionally, type II 5 alpha-reductase mRNA expression was found to have an effect increasing to 1.38 fold. It is not yet known that the treatment of Sparasis crispa increases the expression of type I and type II 5 alpha-reductase mRNA in the DP cells, which can have an excellent treatment effect for Sparasis crispa male hair loss. However, Sparasis crispa increased the mRNA expression of BMP6, FGF7 and CTNNB1 to promote hair production. For this reason, the effect of Sparasis crispa treatment can help in the action, which the final hair generation cycle requires.
\end{abstract}

Keywords: Sparasis crispa, Antioxidant Effect, Dermal Papilla Cell, Cytotoxicity, Type $\square 5$ Alphareductase

\section{Introduction}

Mushrooms have long been accepted into life by ethnic groups around the world, either as a source of nutrients or as a herbal medicine or as a folk medicine. Mushrooms cannot make their own food by photosynthesis because they do not have chlorophyll, even if they are considered a living organism. For this reason, mushrooms are parasitic on the roots or stems of living trees, where they infiltrate the fungus, extend the fungus, and obtain nutrients from it. Mushrooms have a unique aroma and taste, and are known to have various nutrients, as well as various effects such as antioxidant, antiinflammatory, anti-cancer, and immunity enhancement[1].

Sparasis crispa is a mushroom belonging to the family Aphyllophorales and the family Sparassidaceae, which is distributed in South Korea, Japan, China, Europe, North America, and Australia, and is native to the roots or stump of coniferous trees from August to September. The fruit body is 10 25 cm high and is thick at the base and has a common bag of stems, repeated upwards to form a short basin; the basin is flat; the edges are white cabbage, each of which is flat on the outside, yellowish or brown when initially grown. Also, tissues are thin, elastic, and are valuable as food

Received: February 22, 2021; 1st Review Result: April 06, 2021; 2nd Review Result: May 25, 2021 Accepted: June 30, 2021 
because of their subtle scent and texture[2].

They are mainly beta-glucan or proteoglucan, which includes LNT, Sonyfilan (SPG), Crestin (PSK), active hexose correlated compound (AHCC), and polysaccharide-P. These substances act on dendritic cell (DC) or macropage or phagocytosis activities to enhance our body's immune function where DC is evenly distributed across all tissues and works in the early stages of cellular immunity, and one class of DC, Langerhans cells and Kuffer cells, are distributed to the skin and liver, respectively, responsible for the immune function of the tissues[3].

Sparasis crispa has been reported to have many effects such as immune cell activation and tumor growth inhibition[4], anti-inflammatory[5], anti-cancer[6], anti-obesity[7][8], antibacterial and antioxidant[9] and hair growth[10].

Other researches have been conducted on ethyl acetate and water fractions. There was no hair study on boiling water extract. We identified the effect of Sparasis crispa hydrothermal extracts on the cell activity of dermal papilla cells and investigated the antioxidant effects of BMP6, FGF7, FGF10, CTNNB1, Type I and Type II 5 alpha-reductase on mRNA expression.

According to another researcher, the increasing effects of IL-2 and IL-10 were investigated on original Kyungokgo and Iksuyongjingo plus Sparassis crispa on Antioxidant, Immunity Improvement and Sensory Evaluation[11].

The author investigates the effects of antioxidant efficacy, cytotoxicity on dermal papilla cells, and the mRNA expression of BMP6, FGF7, FGF10, CTNNB1, Type 1 and Type II 5 alpha-reductase with specimens obtained from Sparasis crispa hydrothermal extraction and reports significant results.

\section{Materials and Methods}

\subsection{Preparation of samples}

Sparasis crispa used in the experiment was purchased in May 2020 (NO; 2020-0520) from a Baeksan mushroom farm in Hwasun County, and impurities were removed using an ultrasonic washing machine before being used in the experiment.

The mass of the Sparasis crispa medicinal ingredients was measured at $50 \mathrm{~g}$ and then added to the reflux extractor with 2,000 $\mathrm{ml}$ of primary distilled water. After heating the sugar solution for two hours from the time of boiling, the extract was decompressed on the filter paper to produce the filter solution, and the concentrate was obtained using a rotary vacuum evaporator, and dry powder was made using a freeze dryer. Freeze-dried extracts were measured at $16.2 \mathrm{~g}$.

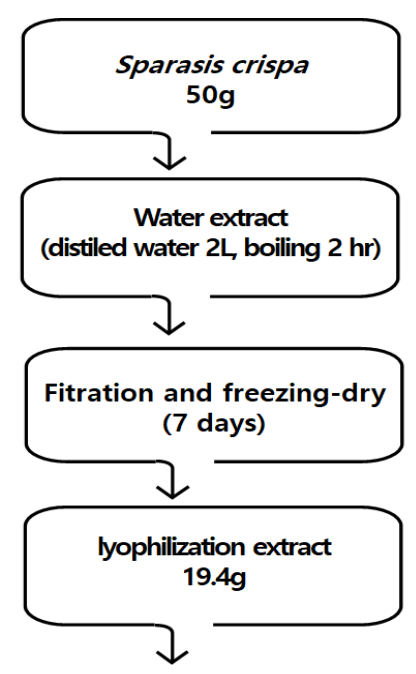

[Fig. 1] Schematic Diagram of the Water Extract Process of Sparasis crispa 


\subsection{Cell Culture}

The cells used in the experiment were dermal papilla cells, and cell lines were sapplied from the dermatology department of Chungnam National University Medical School. The dermal papilla cells used in the experiment were used with DMEM culture solution with $10 \%$ FBS and $1 \%$ anibiotic, and maintained $5 \% \mathrm{CO} 2$ and $37^{\circ} \mathrm{C}$ conditions.

\subsection{Antioxidant Efficacy Evaluation}

The antioxidant effects of Sparasis crispa and resveratrol were identified using ABTS asay. The ABTS free radicals were created by mixing ABTS $7 \mathrm{mM}$ solution and potassium persulfate $2.4 \mathrm{mM}$ solution in the same volume, and then responding after 24 hours of dimming. A total of $80 \mu 1$ of ABTS free radical solution in 96well plate was added and the absorbance of $650 \mathrm{~nm}$ with a microplate reader was measured. It was diluted it with DW and made an ABTS working solution. After mixing $80 \mu 1$ of ABTS working solution and $20 \mu \mathrm{l}$ of sample in 96 well plates, the absorbance level of $650 \mathrm{~nm}$ was measured after 5 minutes of illumination. The antioxidant effects were verified using the following formula.

ABTS radical scavenging activity $(\%)=\left(1-\right.$ A Sample $_{\text {- }}$ Asampleblank $\left./ \mathbf{A}_{\text {Blank }}\right) \times 100$

\subsection{Cytotoxicity Assessment}

The dermal papilla cells were concentrated on 96 well plates at 1 x 104 cells/well and within incubated 24 hours. Sparasis crispa was treated with concentrations of $0.1250 .25,0.5,1$ and $2 \mathrm{mg} / \mathrm{ml}$ and then reacted for 36 hours. Then, $20 \mu \mathrm{l}$ of MTS (3-(4,5-dimethylthiazol-2-yl)-2-(4carboxymethoxyphenyl)-2H-tetrazolium) solution was added and the absorbance of $490 \mathrm{~nm}$ was measured with microplate reader after an hour. The relative cytotoxicity according to the concentration of Sparasis crispa is calculated in the following manner in comparison to the control group.

Cellular activity $(\%)=($ absorbability of sample additive $/$ control group $) \times 100$

\subsection{Quantitative RT-PCR}

Dermal papilla cells were concentrated at 6 well plate with 2 X 105 cells/well and incubated for 24 hours. After processing Sparasis crispa at $0.5 \mathrm{mg} / \mathrm{ml}$ concentration, it will be reacted for 36 hours, then the culture fluid will be removed and will be washed once with PBS. Using the eCube Tissue RNA Mini Kit, RNA was extracted from dermal papilla cells, concentration was quantified using The Qubit 2.0 Fluorometer, and the total volume was adjusted to $8 \mu 1$ using DEPC-treated water in RNA 1 $\mu \mathrm{g}$. After adding $1 \mu \mathrm{l}$ of random hexamer $(100 \mathrm{pmol} / \mu \mathrm{l})$ and $1 \mu \mathrm{lof}$ dNTP mix $(10 \mathrm{mM})$, the water bath was used for 5 minutes at $65^{\circ} \mathrm{C}$. RNase inhibitor $1 \mu \mathrm{l}$, M-MLV RT reaction buffer $4 \mu \mathrm{l}$, M-MLV reverse transcriptase $1 \mu \mathrm{l}$, and DEPC-treated water $4 \mu \mathrm{l}$ were added, and then cDNA was added at $50^{\circ} \mathrm{C}$ for one hour. Then, $5 \mu 1$ of diluted cDNA will be mixed for forward, reverse primer $(10 \mathrm{pmol} / \mu \mathrm{l})$ $1.5 \mu$ l, $2 \mathrm{X}$ Prime Q-mater Mix $10 \mu$ l, D.W. $2 \mu$, and will be performed with qRT-PCR through AriaMx. BMP6, FGF7, FGF10, CTBRA51, SRDA5. 
[Table 1] Primer Sequences

\begin{tabular}{|c|c|c|c|c|}
\hline Gene & & Primer sequence $\quad\left(5^{\prime}\right.$ to $\left.3^{\prime}\right)$ & $\begin{array}{l}\text { Product size } \\
\text { (bp) }\end{array}$ & $\begin{array}{l}\text { Annealing } \\
\text { temp. }\left({ }^{\circ} \mathrm{C}\right)\end{array}$ \\
\hline \multirow[t]{2}{*}{ BMP6 } & $\mathrm{F}$ & CAG TCC TTG TAG ATG CGG AA & 141 & 58 \\
\hline & $\mathrm{R}$ & CAT GAG CTT TGT GAA CCT GG & & \\
\hline \multirow[t]{2}{*}{ FGF7 } & $\mathrm{F}$ & CTG CCA CTG TCC TGA TTT CC & 146 & 58 \\
\hline & $\mathrm{R}$ & TGA TTA CAT GGA AGG AGG GG & & \\
\hline \multirow[t]{2}{*}{ SRD5A1 } & $\mathrm{F}$ & CCAACA GTG GCA TAG GCT TT & 143 & 58 \\
\hline & $\mathrm{R}$ & CTA CCA GTA CGC CAG CGA GT & & \\
\hline \multirow[t]{2}{*}{ FGF10 } & $\mathrm{F}$ & CCC CTT CTT GTT CAT GGC TA & 139 & 58 \\
\hline & $\mathrm{R}$ & TGA GAA GAA CGG GAA GGT CA & & \\
\hline \multirow[t]{2}{*}{ CTNNB1 } & $\mathrm{F}$ & ATT GTC CAC GCT GGA TTT TC & 142 & 58 \\
\hline & $\mathrm{R}$ & AGG TCT GAG GAG CAG CTT CA & & \\
\hline \multirow[t]{2}{*}{ SRD5A2 } & $\mathrm{F}$ & AAG GAC TCC ATT TCC AGT GC & 135 & 58 \\
\hline & $\mathrm{R}$ & ACG GTA CTT CTG GGC CTC TT & & \\
\hline
\end{tabular}

\subsection{Statistical Processing}

The difference between the control group and each experimental group and the mean was analyzed by student's t-test. If the $\mathrm{p}$ value was less than 0.5 , it was judged that there was a statistically significant difference.

\section{Results}

\subsection{Effects of Antioxidant Effects on Antioxidant Effects}

The ABTS assay was conducted using resveratrol, which is well known for its antioxidant efficacy, and it was found that the antioxidant efficacy increased from $10 \mu \mathrm{M}$ to $9.4 \%$ and $100 \mu \mathrm{M}$ to $59.6 \%$, which secured reliability for the ABTS assay. Sparasis crispa was also found to have antioxidant efficacy due to increased concentration, and ABTS radical elimination ability of $1 \mathrm{mg} / \mathrm{ml}$ concentration of Sparasis crispa was $90.2 \%$, indicating excellent antioxidant efficacy.

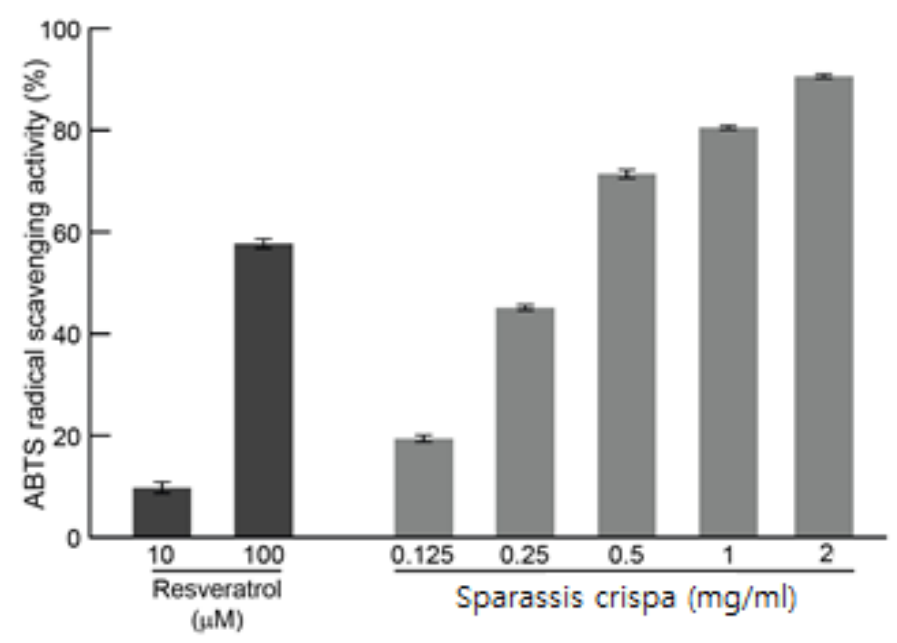

[Fig. 2] ABTS Radical Erasing Activity for Resveratrol and Sparasis crispa 


\subsection{Effect of Sparasis crispa on Cytotoxicity}

In order to check the cytotoxicity of Sparasis crispa to dermal papilla cells, various concentrations of Sparasis crispa were reacted to dermal papilla cells for 36 hours before MTS assay was performed. As a result, the treatment of concentrations $0.125,0.5,1.0$, and $2.0 \mathrm{mg} / \mathrm{ml}$ did significantly affect cell activity, and the treatment of $1 \mathrm{mg} / \mathrm{ml}$ did not significantly affect cell activity at $150.2 \%$. Sparasis crispa at a concentration of $2 \mathrm{mg} / \mathrm{ml}$ was found to reduce the cell activity of DP cells to $160.5 \%$. Referring to the results of these cytotoxicity experiments, subsequent experiments were conducted within the invisible concentration of cytotoxicity.

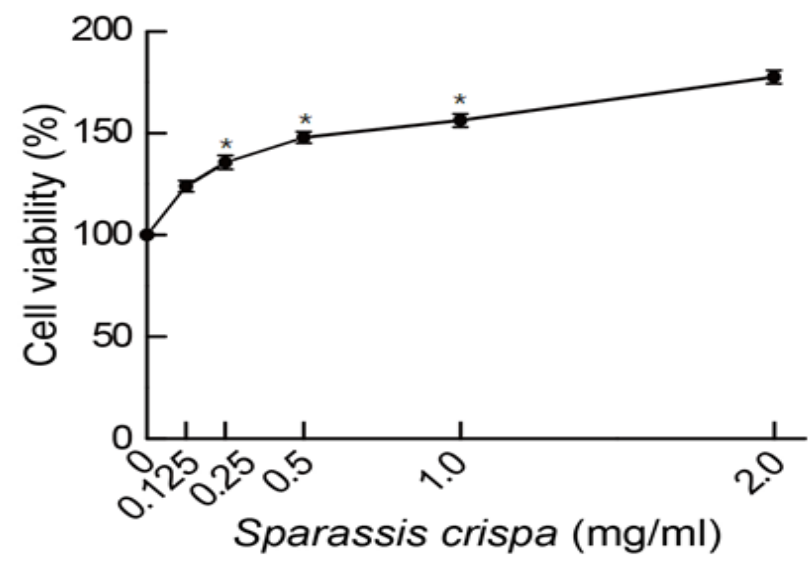

[Fig. 3] Cell Toxicity of Sparasis crispa in Dermal Papilloma Cells. Sparasis crispa was treated at the concentration indicated in dermal papilloma cells for 36 hours. Cell viability was measured by MTS analysis. $* \mathrm{p}<0.5$ vs. comparator.

\subsection{Effects of BMP6, FGF7, FGF10, CTNNB1, Type I and Type $I$ on the Expression of 5 Alpha- Reductase mRNA}

After 36 hours of treatment of Sparasis crispa at a concentration of $0.5 \mathrm{mg} / \mathrm{ml}$ in breast papilloma cells, the relative mRNA expression of mRNA in the control group without processing Sparasis crispa was determined through qRT-PCR. The mRNA expression of BMP6, FGF7, FGF10, the genes of CTNNB1 for alpha-catenin gene, was increased by 1.26 fold, 1.56 fold, 1.42 fold, 1.0 fold and SRD5A1, SRD5A2 mRNA expressions of type I, type II 5 alpha-ductase increased by 1.17 fold and 1.38 fold.

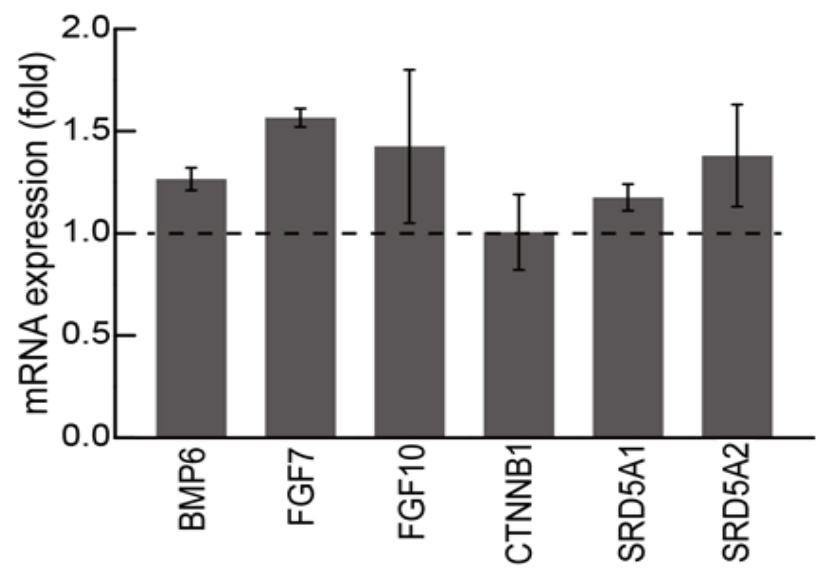

[Fig. 4] BMP6, FGF7, FGF10, CTNNB1, Type I and Type II 5 Alpha-Reductase the Gene Expression to Sparasis crispa. The Dermal Papilloma Cells were Treated at $0.5 \mathrm{mg} / \mathrm{ml}$ for 36 Hours. 


\section{Discussion}

Various diseases that are rapidly increasing in the modern society have characteristics that are mostly caused by inflammatory diseases. Although medicine is continuously making great progress to treat these diseases, adult diseases such as cancer, dementia, and diabetes have not been overcome, and research on natural foods having related physiological activity for treatment and prevention is actively underway[12][13].

Mushrooms belonging to the family of fungus have long been used for food and are attracting attention as an antioxidant that helps with physiological activity or as a functional material that is useful for the treatment of diseases.

Sparasis crispa are called hydrophilic bacteria in China, HanabiratakeM in Japan, Cauliflower mushroom or Crested parasis, Clavaire crayon in French, Morille des pins, Crete de coq, Feisterling digal in German, and koch-ipbeoseos (Kkochbolabeoseos) in North Korea[14].

Carbohydrates make up 70\% of the total nutritional component of Sparasis crispa, of which more than half of carbohydrates are beta-glucan components, and in addition, various components such as glycogen and chitosan are included[15]. The beta-glucan content of flower mushroom may vary depending on the composition of the growth medium. It is more in the stipe section than pileus, and contains up to $59.5 \%$ in stipe[16]. Polyphenol is a generic term for phenolic compounds present in plants, and is a substance that protects itself from various harmful environments as plants grow. Polyphenols are chemical compounds having one or more hydroxyl groups in the benzene ring, and are involved in the mechanism of defense against ultraviolet rays or certain pathogens. Edible polyphenols are diversely distributed from plants to natural products[17]. It contains a large amount of phenolic compounds such as flavonoids, and these components have been reported to prevent gastric ulcers and convulsions caused by oxidative stress, and to prevent and reduce cancer, heart disease and various degenerative diseases[18], decreased IL-2 level and increased Il-10 level in serum at the immunosuppressed rats[11].

Dermal papilla cells play an important role in hair growth and maintenance. The hair cycle can be divided into the anagen stage, the catagen stage, the period when growth is stopped and the bulb shrinks, and the telogen stage, the period when old hair is depilated. In the growing stage, the hair cells in the dermal papilla rapidly undergo mitosis and stimulate the proliferation of keratinocytes that coexist in the hair follicle. The degenerative phase grows slowly while maintaining the shape of the hair. The resting phase is a stage in which the hair follicle is atrophy and the hair follicle is contracted to reduce the depth of the follicle, and the follicle is pushed upward and removed. At this time, when the hair cells of the dermal papilla are activated in the resting phase, the hair follicle gradually descends and when it reaches the dermal papilla, a new hair is formed to replace the existing hair[19].

Androgenetic alopecia is a common hair loss disorder affecting up to $80 \%$ of males by the age of 80 . It is characterized by androgen related progressive thinning of hair in a defined pattern[20]. Since free radicals are very reactive, they induce denaturation of organic substances such as DNA, protein, and lipid, causing various diseases, and these active oxygens are a very important cause of aging. Free radicals induce the inhibition of hair production and may act as a cause of the onset of hair loss. Research results have been reported that the antioxidant tempol has the effect of restoring the hair generation cycle by preventing the oxidation of lipids in mice[21].

Hair loss has been recognized as a series of aging phenomena, but it has recently been revealed that hair loss has been progressed due to various genetic factors, including stress, westernized eating habits, and nutritional imbalances[22].

Oxidative stress-induced lipid oxidation induces the apoptosis of hair follicle cells and induces the cycle of hair production into the catagen. Antioxidant effects that can inhibit active oxygen activity can be very important for hair growth induction and hair loss prevention[23][24]. For this reason, we 
designed experiments on hot water extracts of a variety of natural substances using schematic diagram laboratory methods. The effects of Sparasis crispa on reactive oxygen species(ROS) in this study were identified using ABTS assay. As a result, an increase in antioxidant efficacy was confirmed due to an increase in concentration of Sparasis crispa, especially the ABTS radial elimination efficacy of 1 $\mathrm{mg} / \mathrm{ml}$ concentration of Sparasis crispa was $150.2 \%$ and $2 \mathrm{mg} / \mathrm{ml}$ concentration was $160.5 \%$ which was very good antioxidant efficacy. The various effects of antioxidant effects Sparasis crispa has on promoting hair loss and preventing hair loss when applied to dermal papilloma cells and hair are thought to be identified through further research.

The dermal papilla is a cluster of mesenchymal cells located at the base of the hair follicle which have a number of important roles in the regulation of hair growth[25]. The MTS assay was performed to check the cytotoxicity of the breast papillae cells according to the concentration of Sparasis crispa. As a result, Sparasis crispa at a concentration of $2 \mathrm{mg} / \mathrm{ml}$ reduced the cell activity of the breast papillae cells to $160.5 \%$, but Sparasis crispa at a concentration below $1 \mathrm{mg} / \mathrm{ml}$ was not identified for greater cytotoxicity.

The dermal papilla, which is located at the bottom of the hair follicle, plays an important role in hair growth because it regulates the generation of hair follicles and the generation cycle of hair with the help of several regulatory factors. Among several regulatory factors, the increase of $\beta$-catenin through Wnt signaling is known to be involved in the formation and regeneration of hair follicles by promoting hair follicle formation in dermal papilla cells. The expression of FGF7 and FGF10, which play a role in activating the early stages, is known to stimulate hair follicle production[26]. Most of the hair loss is caused by male pattern hair loss, and DHT, which is the main cause of male pattern hair loss, induces contraction of the dermal papilla and hair follicles and induces the hair growth cycle from the growth phase to the resting phase. It promotes the expression of transforming frowth factors- $\beta 1$ and $\beta 2$ that induces hair loss[27]. Seeing the potential of SRD5 $\alpha 2$ as a target for androgen synthesis, pharmaceutical companies developed 5 $\alpha$-reductase inhibitors (5ARIs), such as finasteride (FIN) and dutasteride (DUT) to target SRD5 22 in benign prostatic hyperplasia and androgenic alopecia[28].

Inhibition of type II 5 alpha-reductase enzyme activity is critical for men's hair loss treatment. According to previous experimental data, the expression of type II 5 alpha-reductase gene in Houttuynia cordata and Cynanchum wilfordii was decreased. Sparasis crispa were rather increased[29][30]. Hair growth effect by separation of ethyl acetate layer and water layer of flower mushroom extract in C57BL/6 mice showed distinct hair growth effect and increased hair follicle length even in histological analysis[10]. Significant change in mRNA expression of type I 5 alphareductase could be identified if Sparasis crispa with a concentration of $0.5 \mathrm{mg} / \mathrm{ml}$ was treated in dermal papilloma cells. Additionally, type II 5 alpha-reductase mRNA expression was found to have an effect of increasing to 1.38 fold. Type I 5-alpha-reductase is widely distributed in the sebum and sweat glands of the skin, while type II 5-alpha-reductase is mainly distributed in whiskers, prostate and scalp hair follicles. It is not yet known that the treatment of Sparasis crispa increases the expression of type I and type II 5 alpha-reductase mRNA in the dermal papilloma cells, which can have an excellent treatment effect for Sparasis crispa male hair loss. However, Sparasis crispa increased the mRNA expression of BMP6, FGF7 and CTNNB1 to promote hair production. For this reason, the effect of Sparasis crispa action on the final hair generation cycle requires further research. It is considered necessary to conduct additional in vivo tests to determine whether changes in dermal papilla cell gene expression following treatment with Sparasis crispa can induce follicle formation and hair growth. 


\section{Conclusion}

In this study, samples obtained by hydrothermal extraction of Sparasis crispa were examined for antioxidant efficacy, cytotoxicity to dermal papilloma cells, and the effect on mRNA expression of genes related to hair growth and hair loss.

The antioxidant effect of Sparasis crispa was confirmed through ABTS assay. After 36 hours of treatment of Sparasis crispa in various concentrations of dermal papilloma cells, MTS assay was performed and no significant cytotoxicity was confirmed at $1 \mathrm{mg} / \mathrm{ml}$. The mRNA expression of FGF7, BMP6, CTNNB1 was increased to 1.5 fold, 1.3 fold, and 1.2 fold Sparasis crispa at a concentration of $0.5 \mathrm{mg} / \mathrm{ml}$ treated in dermal papilloma cells for 36 hours. The mRNA expression of type I 5 alphareductase was induced to 1.4 fold and type II 5 alpha-reductase was induced to 1.38 fold Sparasis crispa at a concentration of $0.5 \mathrm{mg} / \mathrm{ml}$ treated in dermal papilloma cells for 36 hours.

Sparasis crispa increased the mRNA expression of BMP6, FGF7 and CTNNB1 to promote hair production. For this reason, the effect of Sparasis crispa action on the final hair generation cycle requires further research. As the result of the RNA level, it is thought that the protein level western blot analysis method will be added. The effect of Sparasis crispa extract on hair growth and inhibition of hair removal C57BL 6 mice should be further investigated.

\section{References}

[1] G. H. An, J. G. Han, J. H. Cho, Antioxidant activities and $\beta$-glucan contents of wild mushrooms in Korea, Journal of Mushroom, (2019), Vol.17, No.3, pp.144-151, https://doi.org/10.14480/JM.2019.17.3.144

[2] S. Y. Seo, Y. J. Yoo, G. T. Jung, J. Ryu, B. R. Ko, J. S. Choi, M. K. Kim, Optimal condition for mycelial growth of Sparassis crispa, Journal of Mushroom Science and Production, (2005), Vol.3, No.2, pp.45-51, DOI : http://dx.doi.org/

[3] T. Yadomae, Sparassis crispa, Jongsinsegyesa, (2001)

[4] I. K. Kim, J. Y. Yoo, Y. C. Shin, Y. C. Yun, Effect of Sparassis crispa extracts on immune cell activation and tumor growth inhibition, Journal of Life Science, (2013), Vol.23, No.8, pp.984-988, https://doi.org/10.5352/JLS.2013.23.8.984

[5] W. S. Choi, P. G. Shin, Y. Y. Bok, N. H. Jun, G. D. Kim, Anti-inflammatory effects of Sparassis crispa extracts, Journal of Mushroom, (2013), Vol.11, No.1, pp.46-51, https://doi.org/10.14480/JM.2013.11.1.046

[6] M. H Choi, H. K. Han, Y. J. Lee, H. G. Jo, H. J. Shin, In vitro anti-cancer activity of hydrophobic fractions of Sparassis latifolia extract using AGS, A529, and HepG2 cell lines, Journal of Mushroom, (2014), Vol.12, No.4, pp.304-310, https://doi.org/10.14480/JM.2014.12.4.304

[7] M. A. Lee, J. K. Park, M. H. Um, J. W. Jeon, J. M. Lee, Y. K Park, Lipolytic effect of Sparassis crispa extracts in differentiated 3T3-L1 cells and high fat diet-induced obese mice, Journal of the Korean Society of Food Science and Nutrition, (2012), Vol.41, No.12, pp.1708-1715, https://doi.org/10.3746/jkfn.2012.41.12.1708

[8] M. R. Lee, J. G. Hou, S. Begum, Y. B. Wang, D. S. Oh, A. J. Wi, B. S. Yoon, C. K. Sung, Anti-obesity effects of Sparassis crispa on high-fat diet-induced obese mice, Journal of Life Science, (2014), Vol.24, No.9, pp.952-958, https://doi.org/10.5352/JLS.2014.24.9.952

[9] M. C. Kim, J. S. Kim, M. S. Heo, Antibacterial antioxidant and antitumor activities of mushroom mycelium mixed culture extracts, Korean Journal of Biotechnol Bioeng, (2008), Vol.23, No.2, pp.158-163, UCI : G704SER000001461.2008.23.2.002

[10] E. M. Ryu, H. J. Shin, Hair growth effect of ethyl acetate and water fractions of Sparassis crispa extracts on hairremoved C57BL/6 mice, Korean Journal of Aesthetics and Cosmetology, (2011), Vol.9, No.4, pp.1-10, UCI : G704SER000010442.2011.9.4.034 
[11] C. S. Na, W. Shin, Y. M. Lee, Y. S. Moon, H. K. Noh, S. H. Seo, H. S. Son, Effect of Original Kyungokgo \& Iksuyongjingo plus Sparassis crispa on Antioxidant, Immunity Improvement and Sensory Evaluation, The Korea Journal of Herbology, (2016), Vol.31, No.4, pp. 43-51, https://doi.org/10.6116/kjh.2016.31.4.43

[12] Y. S Jung, S. Y. Park, S. Y. Jung, Effects of Angelica gigas and Achyranthes bidentata on Microorganisms in Seoborrheic and Hair Loss Scalp, International Journal of Beauty Science and Technology, (2017), Vol.1, No.1, pp.1-6, DOI:10.21742/ijbst.2017.1.1.01

[13] R. J. Song, F. H. Wu, G. Liu, L. Zhu, D. H. Zhu, Z. Li, Rapid Identification of Cancerous Cell Lines and Evaluation of Cytotoxic Effects on Cancer Cells with VUV-PIMS, International Journal of Advanced Nursing Education and Research, (2017), Vol.2, No.2, pp.75-94.

[14] Y. B Yun, Joseon Mushroom Encyclopedia, Baeggwasajeon, (1978)

[15] D. S. Oh, H. S. Kim, B. S. Shim, A. J. Wui, B. S. Yoon, K. W. Kim, S. J. Wang, Effect of mycelial culture of cauliflower mushroom (Sparassis crispa) using LED lighting operation, Journal of Mushroom, (2013), Vol.11, No.1, pp.24-31, https://doi.org/10.14480/JM.2013.11.1.024

[16] S. J.Wang, H. S. Kim, A. J. Wi, B. S. Yoon, W. S. Park, H. H. Park, D. S. Oh, Optimal Medium Composition of Cauliflower Mushroom (Sparassis latifolia) Cultivation Using Douglas Fir Wood Chip and Comparison of The $\beta$ glucan Contents of The Fruiting Body, Journal of the Korean Wood Science and Technology, (2014), Vol.42, No.4, pp.428-434, https://doi.org/10.5658/WOOD.2014.42.4.428

[17] H. J. Jeon, H. J. Kwon, Antioxidant effects and functional evaluation of Gynura procumbens extract as a collaboration material for cosmetics and functional food, Asian Journal of Beauty and Cosmetology, (2014), Vol.12, No.4, pp.499-507, UCI : G704-SER000010442.2014.12.4.002

[18] M. H. Choi, H. J. Shin, Anti-oxidative and anti-melanogenesis effects of blueberry extract, Asian Journal of Beauty and Cosmetolog, (2015), Vol.13, No.2, pp.261-266, UCI : G704-SER000010442.2015.13.2.01

[19] J. W. Oh, J. Kloepper, E. A. Langan, Y. S. Kim, J. Yeo, M. J. Kim, T. C. Hsi, C. Rose, G. S. Yoon, S. J. Lee, J. Seykora, J. C. Kim, Y. K. Sung, M. Kim, R. Paus, M. V. Plikus, A Guide to Studying Human Hair Follicle Cycling In Vivo, Journal of Investigative Dermatology, (2016), Vol.136, No.1, pp.34-44, DOI: 10.1038/JID.2015.354

[20] K. York, N. Meah, B. Bhoyrul, R. Sinclair, A review of the treatment of male pattern hair loss, Expert Opin Pharmacother, (2020), Vol.21 No.5, pp.603-612, DOI: 10.1080/14656566.2020.1721463

[21] N. Liu, L. H. Wang, L. L. Guo, G. Q. Wang, X. P. Zhou, Y. Jiang, J. Shang, K. Murao, J. W. Chen, W. Q. Fu, G. X. Zhang, Chronic Restraint Stress Inhibits Hair Growth via Substance P Mediated by Reactive Oxygen Species in Mice, PLoS One, (2013), Vol.8, No.4, e61574, DOI: 10.1371/journal.pone.0061574

[22] E. M. Peters, P. C. Arck, R. Paus, Hair growth inhibition by psychoemotional stress: a mouse model for neural mechanisms in hair growth control, Experimental Dermatology, (2006), Vol.15, No.1, pp.1-13, DOI:10.1111/j.09066705.2005.00372.x

[23] A. Naito, T. Midorikawa, T. Yoshino, M. Ohdera, Lipid peroxides induce early onset of catagen phase in murine hair cycles, International Journal of Molecular Medicine, (2008), Vol.22, No.6, pp.725-729, https://doi.org/10.3892/ijmm_00000078

[24] P. H. Kim, K. N. Kim, Comparison of the difference of appearance satisfaction and self-esteem according to selfcoordination of nursing college students, International Journal of Advanced Nursing Education and Research, (2019), Vol.4, No.1, pp.13-18.

[25] H. Topouzi, N. J. Logan, G. Williams, C. A. Higgins, Methods for the isolation and 3D culture of dermal papilla cells from human hair follicles, Experimental Dermatology, (2017), Vol.26, No.6, pp.491-496, DOI: 10.1111/exd.13368

[26] D. Enshell-Seijffers, C. Lindon, M. Kashiwagi, B. A. Morgan, Beta-catenin activity in the dermal papilla regulates morphogenesis and regeneration of hair, Dev Cell, (2010), Vol.18, No.4, pp.633-642, DOI: 10.1016/j.devcel.2010.01.016

[27] J. I. Kang, S. C. Kim, M. K. Kim, H. J. Boo, E. J. Kim, G. J. Im, Y. H. Kim, J. W. Hyun, J. H. Kang, Y. S. Koh, D. B. Park, E. S. Yoo, H. K. Kang, Effects of dihydrotestosterone on rat dermal papilla cells in vitro, European Journal 
of Pharmacology, (2015), Vol.757, pp.74-83, DOI: 10.1016/j.ejphar.2015.03.055

[28] J. Robitaille, V. S. Langlois, Consequences of steroid-5 $\alpha$-reductase deficiency and inhibition in vertebrates, General and Comparative Endocrinology, (2020), Vol.290, p.113400, https://doi.org/10.1016/j.ygcen.2020.11340

[29] N. J. Cho, B. K. Lee , W. H. Lee, K. K. Kim, H. S. Han, Investigation of Antioxidant Activity of Houttuyniae Herba and its Effect on 5 $\alpha$-reductase Gene Expression in Dermal Papilla Cells, Journal of Physiology \& Pathology in Korean Medicine, (2017), Vol.31, No.6, pp.356-361, https://doi.org/10.15188/kjopp.2017.12.31.6.356

[30] N. J. Cho, Y. H. Choi, H. L. Jeon, W. H. Lee, K. K. Kim, H. S. Han, Investigation of Antioxidant Activity of Cynanchi Wilfordii Radix and Inhibitory Effect of $5 \alpha$-reductase mRNA in Human Dermal Papilla Cells, Journal of Physiology \& Pathology in Korean Medicine, (2017), Vol.31, No.6, pp.374-379, https://doi.org/10.15188/kjopp.2017.12.31.6.374 